Article

\title{
On Triads, Teleology, and Tensions in Antiquities 18-20
}

\author{
Daniel R. Schwartz
}

Department of Jewish History and Contemporary Jewry, The Hebrew University of Jerusalem, Jerusalem 91905, Israel; danielr.schwartz@mail.huji.ac.il

Received: 27 November 2019; Accepted: 3 January 2020; Published: 12 January 2020

\begin{abstract}
Josephus liked to organize material in three-part structures, which imparted a sense of completion by indicating to readers that an end had been reached. This study focuses on Books 18-20 of Josephus's Antiquities, which are organized as such a triad: Book 18 opens Roman rule in Judea and adumbrates the final clash and catastrophe, Book 19 creates some suspense by detailing two possible interruptions that could have changed the course of history but in the end came to nothing, and so Book 20 resumes the story from the end of Book 18 and takes it down to the destruction of Jerusalem. Moreover, all three books, together, form a unit in a larger triad: the story told, in the second half of Antiquities, of Judea's move from sovereignty under the Hasmoneans (Books 12-14), to nominal sovereignty under Herod (Books 15-17), to subjugation to Rome (Books 18-20). This focus on political history is, however, contradicted in various ways, both by Josephus's development from a Judean into a Jew of the Diaspora, who focused more on religion than on state, and by various sources used by Josephus, that pulled in other directions.
\end{abstract}

Keywords: Josephus; Antiquities; Judean; triads; teleology

\section{Introduction}

Books 18-20 of Josephus's Antiquities, of which Louis Feldman's 1965 Loeb Classical Library edition remains a masterful contribution to Josephan scholarship, recount the history of Judea from 6 CE until 66 CE. Those were the fateful six decades between the inception of direct Roman rule in Judea and the outbreak of the rebellion that would culminate a few years later with the destruction of the Temple of Jerusalem and the city as well (in $70 \mathrm{CE}$ ). In this brief essay, I will first argue that these three books are arranged in a clear tripartite structure, and also that, taken together, they fulfill a clear purpose, defined by their location, within the tripartite structure of the second decade of Josephus's Antiquities. Then I will focus on two factors that pull nevertheless in other directions and, thereby, compete with that purpose. Those factors are, on the one hand, the change in Josephus's own circumstances and interests, in his move from Judea to Rome and the destruction of the Temple, and, on the other hand, his use of sources that reflect other circumstances and interests.

\section{Teleology in Antiquities 18-20: The Final Third of a Tripartite Political History}

Josephus, as many others, liked to divide his material into threes. Some obvious examples include: the three Jewish sects, three periods of Herod's rule, three final Roman governors before the rebellion of $66 \mathrm{CE}$, three main theaters of war in that rebellion, three parties in Tiberias, three main factions of Jewish rebels in Jerusalem, three opinions in Titus's council prior to the destruction of the Temple, and so on.

As is familiar to anyone who was brought up on stories about three bears or three little pigs, or, in antiquity, on Aristotle's analysis of speeches according to the orator, the addressee, and the topic; Polybius's cycle of constitutions that move from monarchy to aristocracy to democracy via tyranny, 
oligarchy, and ochlocracy, and then start over again; Cicero's division of all law into ius gentium, ius civile, and ius naturale; and Caesar's report that he "came, saw, and conquered" a country that just happened to be divided into three parts-such triads, when they appear in literature, are useful for authors and have, correspondingly, their meanings for readers. Authors, on the one hand, often use them not just to enumerate three items, but rather, to indicate a whole, whether they are the first two steps and then the final one, or rather, two extremes and then a center. One way or another, omne trium perfectum, or three strikes and you are out. Thus, in the above-mentioned cases from Josephus the use of triads is evident: the Essenes ascribe everything to providence, the Sadducees ascribe nothing to providence, and the Pharisees have a middle view, ascribing to providence control of some things but not of all (Ant. 13.171-173); Herod's reign is divided into an introductory rise to power, a successful middle stage, and a catastrophic third one ${ }^{1}$; of the last three Roman governors before the rebellion, in which Festus tried hard to preserve law and order, Albinus pretended to but was in fact corrupt, and Florus was worse and did not even try to hide it, and so it was clear that things would explode during his governorship (War 2.271-277); of the three parties in Tiberias, one favored peace, one favored war, and one pretended to have a middle view (namely, to be undecided), although in fact it too wanted war (Life 35-36); ${ }^{2}$ of the three rebel factions in Jerusalem, Eleazar's men attacked John's, John's attacked Simon's, and Simon's harassed the city (War 5.21); the Romans eventually suppressed the rebellion first in the north of the country, then in the middle, and finally in the south, ${ }^{3}$ and while some of Titus's officers favored destroying the Temple no matter what, and others, including Titus, held that it should be preserved no matter what, there were also those who pleaded for an intermediate position, according to which the Temple should be destroyed if the Jews persisted in using it as a stronghold, but spared if they did not (War 6.236-243). This all must have come fairly naturally for a writer who opens another of his books with the announcement that he wishes to respond to the Jews' detractors, to those who are ignorant about them, and moreover, to all who wish to know the truth about them (Against Apion 1.3).

As for readers, on the other hand, since they are used to such tripartite structures, they know, or are at least entitled to expect, when they begin reading the third section of a unit large or small, and while reading their way through it, that it is the final one which must somehow bring the work to completion. Anyone who hears a story that begins, "Once upon a time there were three men: one was very fat, one was very skinny," may and indeed should legitimately expect to hear that the third was of average size, just as anyone who hears a story that begins "Once upon a time there were three men: one was very fat, one was of average size," may and indeed should legitimately expect to hear that the third one was very skinny.

These opening comments, about tripartite divisions and Josephus's predilection for them, apply in two ways to the last three books of his Antiquities, Books 18-20. First, and most obviously, they have everything to do with the way these three books relate to each other and form a whole. Second, and only somewhat more subtly, they also relate to how these three books, taken together, constitute the last third of the second (and final) decade of Antiquities.

Turning first to the structure of these three books, note that the first (Book 18) and the last (Book 20) consist of two segments of the same unidirectional story; what separates them (Book 19) turns out, in the end, to be only a diversion that creates some tension by raising hope for a while that the story might not be completed. That tension is supplied by the two stories that compose Book 19. The first of

1 See esp. the transitions at War 1.400 and 1.431. Josephus's organization of Herod's reign was from the outset the basis of Schürer's classic treatment: "Seine Regierung lässt sich in drei Perioden theilen" (original emphasis) (Schürer 1874, p. 198; Schürer, vol. 1, p. 296: "His reign may be divided into three periods"), and his presentation has been reproduced in any number of subsequent accounts.

2 So too, at Life 123-125, we read that of the three main cities of the Galilee, one remained peaceful, one rebelled, and one tended to the latter position but refused to admit it openly.

3 On this, concerning which Josephus actually has two views, punctuated respectively by three cases of $\dot{\varepsilon} \alpha \lambda \omega(4.120,439$; 6.435) and three cases of "demonic" intervention (4.75-76; 6.252; 7.317-319), see Schwartz 2015. 
them is the long story of the assassination of Gaius Caligula, whose reign brought Judea to the brink of rebellion and catastrophe in Book 18. The assassination story raises the hope for better times-that the Republic might be restored. Yet in the end that did not happen, and Gaius was simply replaced by another emperor, Claudius. Similarly, the second story of Book 19, the story of the monarchy of Agrippa I, which actually put an end to direct Roman rule in Judea for a few years, raises the hope of restoration of Judean autonomy and even (given the identity of Agrippa's paternal grandmother) the possibility of renewed Hasmonean rule. But that too turns out to have been only a passing anomaly, for by the end of Book 19, Agrippa dies suddenly, and Roman provincial rule resumes as if nothing had happened. Thus, by the end of Book 19, the empire in general, and imperial rule in Judea in particular, are back on course as they were at the end of Book 18-so the story which left off at the end of Book 18 can now resume in Book 20 on the same restored terms, and can continue its downhill course to the eve of rebellion and destruction. That Book 19 is, in the grand scheme of things, only an excursus that fills out the details of a datum already presented in Book 18 (Gaius's death (Ant. 18.305-307)) and lends some tension to the otherwise unidirectional main story is already suggested by the fact that, of the sixty years to which these three books are devoted, all but three are covered in Book 18 (6-41 CE) and Book 20 (44-66 CE), leaving only a few years in between for Book 19. Although Josephus's account of those years, which opens with the hope-arousing death of Gaius but ends with the hope-dashing death of Agrippa, affords him an interesting opportunity to express his views on kings who aspire to divinity and on other topics, it contributes nothing essential to the development of the book's story.

That appears to be obvious. The other way in which tripartite division is applicable to Antiquities 18-20 is somewhat more subtle. It has to do with how those three books, as a unit, function as the final third of the second decade of Antiquities. They complete the political history of the Second Temple period, to which that second decade is devoted. That history too is told as a tripartite story, of which the structure is just as those we saw above: an extreme, a middle position, and the other extreme. More specifically, we should point here to the cases in which the middle position is one that pretends to be one extreme but is really the other, such as those at War 2.271-277, Life 35-36, and Life 123-125, which were mentioned above. Namely, after a Hasmonean story in Books 13-14, which is about real Judean sovereignty, and Herod's story in Books 15-17, which is about merely nominal Judean sovereignty (for the Judean king was in fact a vassal of Rome and, moreover, was not really a Judean), Books 18-20 tell the story of Judea under direct and explicit Roman rule (under unambiguously gentile governors sent from Rome), and how that came to include the rest of Palestine as well and culminated in the destruction of Jerusalem and the Temple. That is, the last decade of the book basically tells a three-stage story of a three-part decline from freedom to nominal freedom to explicit subjugation, which engenders destruction, whereupon (at the end of Book 20—§258) Josephus refers his readers to his Judean War for the details of the final catastrophe.

The above summary does not account for the first two books of the decade, but they play an important role. To understand, note that since the first decade concluded with the destruction of the sovereign Judean monarchy and the exile of the Judeans to Babylonia, while the new tripartite story Josephus wanted to tell about the Hasmoneans, Herod, and the Romans was about the loss of sovereignty, it was necessary for sovereignty first to be reestablished. That is the point of Books 11-12: these two books amount to something of an introduction that sets the stage for the main story. ${ }^{4}$ Thus, already the first lines of Book 11 summarize the Judeans' situation in Babylonian exile as one of captivity and suffering, while the next lines (11.2) announce God's promise to put an end to their servitude $(\delta o v \lambda \varepsilon i \alpha) .{ }^{5}$ Yet that does not happen in Book 11. Rather, it happens in two stages, one each in Book 11 and Book 12: in Book 11 Cyrus allows the exiles to return to Judea, and then, after the Persians are defeated by Alexander (by the end of Book 11), Book 12 takes the story down to the time at

4 For such opening two-part prologues, cf. 2 Maccabees 1-2 and Luke 1-2. Not everything comes in threes.

5 That freedom, as the antithesis of servitude, is a prominent theme in Antiquities was underlined by Feldman 1998, p. 148: "One might almost say that liberty is the leitmotif of the history of the Jewish people as Josephus sees it." 
which Judas Maccabeus reestablished liberty $\left(\dot{\varepsilon} \lambda \varepsilon v \theta \varepsilon \rho^{\prime} \alpha\right)$ instead of servitude $\left(\delta o v \lambda \varepsilon^{i} \alpha\right)$. That is how Judas's accomplishments are summarized, emphatically, both at the very end of Book 12 (\$434) and at the very opening of Book $13(\S 1)$. With that fulfillment of the promise made at the outset of Book 11 , the introduction is now complete and the new downhill story, in three stages, may begin: from sovereignty in Books 13-14, to the semblance of sovereignty in Books 15-17, to the loss of sovereignty in Books 18-20.

Indeed, it seems clear, from the end of the last book in each of those three sections, Books 14, 17, and 20, as opposed to the ends of the other books, that those sections were so defined in Josephus's mind. For while Book 13 ends with the undated demise of Salome Alexandra, who was just another passing member of the Hasmonean dynasty, Book 14 ends with a formal dating (14.487), which in and of itself denotes a watershed ${ }^{6}$; correspondingly, the final lines of Book 14 include a formal epitaph of the whole Hasmonean dynasty ("It was a splendid and famous house ... ") and an authorial signing-off ("This, then, is the end of the Hasmonean line as I received it"). Similarly, while Books 15 and 16 end at passing moments in Herod's career, Book 17 ends with Archelaus's banishment and the annexation of his territories to Syria, with, that is, the final end of Herod's rule in Judea. In contrast to Book 18, which ends rather haphazardly with a long excursus (on the Jews of Babylonia), and to Book 19, which opens with another long one (on Gaius) and ends with the appointment of yet another new Roman governor of Judea, who arrives at the beginning of Book 20 (so there is no noticeable transition from Book 19 to Book 20), Book 20 ends very formally, with a review of the high priesthood and dated notices both of the end of the narrative in 66 CE (20.257) and of the book's completion in 93/93 C.E. (20.267). Thus, readers should have no difficulty in realizing that Books 13-14, 15-17, and 18-20 are major divisions of the work. Once they get to the end of the work and realize that it has only twenty books (if they did not know it to begin with), it will be all the simpler for them to view the book as broken down into two decades, of which each ends with the destruction of a temple in Jerusalem, and so to understand Books $11-12$ as the introduction of the second decade.

Readers, then, who begin reading Antiquities 18 after making their way through the preceding books, should know that they are beginning the final stage of a story (and shortly we shall see additional evidence that shows they should know that), and so they may, and should, expect that it will complete the preceding two stages: if they were about home rule and nominal home rule, now they have come to the stage of explicitly foreign rule. Indeed, they were told as much at the very end of Book 17. Moreover, we should probably assume that many ancient readers came to the book with the foreknowledge that Judea had, by their time, become a Roman province, so they had been waiting for that part of the story. ${ }^{7}$ Antiquities 18 immediately confirms their expectation, insofar as it opens by providing in its account of Quirinius, some of the details of the Roman absorption of Judea into the empire and confiscation of Archelaus's property, and the appointment of a Roman governor, Coponius.

Apart from knowing that Judea was a Roman province, we may probably assume that many or most first- and second-century readers of Antiquities will have come to the book not only with the knowledge that Judea was, in the first century, a Roman province, but also that the story ended badly, with a Judean rebellion that was put down quite successfully by the Flavians. Josephus's first work, the Judean War, was only one of the many ways in which the Flavians ensured that knowledge of that was very widespread; there were also other literary works, Judea capta coins, and monuments. ${ }^{8}$ All the more reason that readers, in turning to the part of Antiquities that deals with Judea under direct Roman rule, namely Books 18-20, must have come with the expectation that they would hear what went wrong.

6 Compare, for example, Thucydides 2.2; 1 Maccabees 1:10, Luke 3:1-2.

7 There is no need to enter, here, the technical question of whether, or in what ways, it was an "independent" province or, rather, part of Provincia Syria.

8 See Millar 2005, pp. 101-28, also Barnes 2005, pp. 130-31. 
Here too, Josephus confirms their expectations. Namely, right after his opening report about Quirinius (18.1-2) Josephus reports a rebellion and uses it as a springboard to expand more generally about the troubles and calamities that ensued until eventually they culminated in the destruction "even

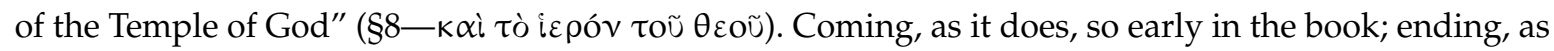
it does, the list of calamities that ensued from rebelliousness; and implying, as it does, that it was the worst of them, this reference to the destruction of the Temple amounts to a statement of the book's remaining agenda. Readers who came to Antiquities knowing — as many certainly did-that the story ended with the Roman destruction of Jerusalem and the Temple are thus reassured that the work will indeed allow them to understand how that happened. That is, they may confidently begin reading on the assumption that the book will tell them about a clash between Judeans and Romans.

\section{Two Sources of Tension}

With the citation of Ant. 18.8, however, we have come to the first of two factors that creates major tension in Antiquities 18-20: Josephus's explicit and even pronounced interest in religion. For if we were to consider everything said above apart from the citation of Josephus's reference to "the Temple of God," we would summarize it as presenting Antiquities as a chronologically arranged work of political history. That characterization of the work is bolstered by the fact that the work is structured and punctuated according to the changing identity of the sovereign power, just as one might write a history of any state divided into chapters defined by its successive rulers. Indeed, there is good structural reason to think of the second decade of Antiquities as the history of Judea under successive sovereigns, just as within Antiquities 18-20 the work is organized according to the terms of office of successive Roman governors. ${ }^{9}$ Often, in fact, it seems that Josephus used whatever a first-century equivalent of a shoe box was to organize his materials behind dividers bearing the names of the successive Roman governors of Judea, just as, in earlier parts of his story, he used dividers bearing the names of the successive kings of Judea in the Monarchy period or successive high priests in the Persian period. ${ }^{10}$ So a reading of Ant. 18-20 on the basis of the expectation that its focus is on Judeans versus Romans is reinforced by the very scaffolding of the work.

However, even apart from the fact that much in Antiquities 18-20 deals with Jews outside of Judea, and even outside the Roman world, ${ }^{11}$ it is also the case that the abrupt reference to God, in 18.8, along with the statement that the worst calamity was the destruction of His temple, points away from a political history. Indeed, Josephus does not even refer to the destruction of Jerusalem here, something that readers could have taken to refer to a country's capital city; rather, he refers to the destruction of the Temple of God. So do the very next words, in $\S \S 8-9$, which explain that what caused the Temple to be destroyed by the flames "of the(ir) enemies" ( $\tau \widetilde{\omega} \vee \pi \mathrm{o} \lambda \varepsilon \mu$ í $\omega v)$ was the "innovation" concerning

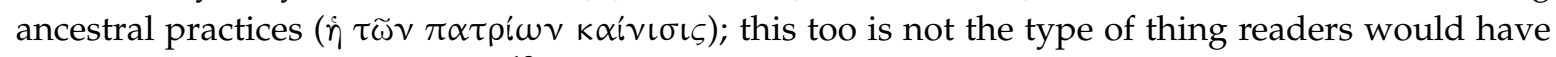
expected from a political history. ${ }^{12}$ And the same may be said, of course, of the next very long section of the book (\$§10-25), which is an excursus on Jewish sects. In his discussion of the first three sects, Josephus says not a word about anything having to do with sovereignty, politics, or Romans. Rather, he refers to God several times and focuses on issues of religious belief and practice. Indeed, even when he turns to the "fourth philosophy," that of the rebels against Rome, he portrays their passion for liberty as a result of their belief that God alone is their leader and master (\$23). Readers, that is, who come to Antiquities 18-20 with the expectation of reading the third section of a treatise on how Judea came to be

9 For an attempt to set this structure out in detail, see Schwartz 1992, pp. 189-93.

10 For two striking examples of such "dividers," see Ant. 11.297 and 18.34-35. The former comprises the end of a section devoted to one high priest (Eliashib), an empty section devoted to his son, Jehoiada (concerning whom Josephus had, apparently, nothing to report, but he nonetheless reflected his existence), and the beginning of a new section concerning the next successor to the position, Johanan. As for Ant. 18.33-35, it seems quite obvious to be a case in which Josephus had nothing behind his divider for the governorship of Valerius Gratus, apart from items culled from a list of high priests.

11 Esp. 18.65-84, 310-379; 19.278-291; and 20.17-96.

12 On the text here, see the apparatus to Niese's edition. 
subjugated by Rome, and happily began reading the first few lines of the book, are very quickly put on notice that, apart from, or perhaps even more than, the story about the Judeans and the Romans in the first century, the author is quite interested in another story: that of the Jews and their God.

This theme will not surprise readers who have read Antiquities from its outset, however, for the same orientation may be found already at the outset of the book, as well as frequently in its course. ${ }^{13}$ Here it is important to emphasize that this theme is very basic to these last books as well. Suffice it to say that Books 18-20 are positively bracketed by the claim that it is innovation concerning

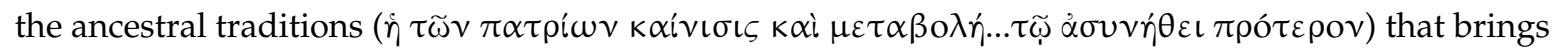
about catastrophe; that claim, stated so prominently in $\S 9$ with regard to the Judean rebels against Rome, who are portrayed as if they were devotees of a new philosophy of Judaism that deviates from the three legitimate ones, recurs just as prominently at the end of the story in Antiquities 20. There Josephus, in condemning a certain change in cultic practice (concerning the Levites' garments),

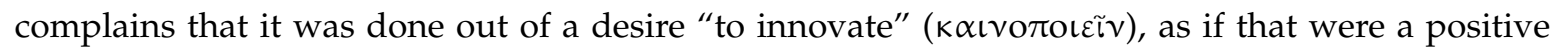
motivation; in fact, he declares, "all of this contravened the ancestral laws, and once they had been violated it was impossible that judgment not be imposed" (Ant. 20.218). Thus, just as much as rebellion against Rome, and the ensuing destruction, brackets these three books, so too does the theme that violation of ancestral tradition entails punishment. Indeed, by bracketing the three books, as it does, this theme becomes the major guide to its interpretation. Yet the notion, that it is the Jews' violation of their national traditions that engendered the Roman destruction of Jerusalem, that something as exotic and picayune as changes in the Levites' clothing, can account for Titus's triumph, is surely far from the expectations of any reader who began reading Antiquities 18-20 to learn about the Roman destruction of Jerusalem.

It is, however, an old and well-established theme in biblical and Jewish historiography. It is the hallmark of the Deuteronomistic understanding of history, whether as set out theoretically in Moses's song (Deut 32) or as illustrated time and again in the stories of Judges and Kings, and it is the hallmark of the classical prophets' understanding of how it is that an all-powerful God could let His people suffer so terribly at the hands of other kingdoms. Closer yet to Josephus, his message, at 18.8-9 and at 20.218 , is precisely paralleled by that of 2 Maccabees, which after referring to the young priests who neglected ancestral tradition, go on to inform the readers about what is next to come:

For this reason, heavy disaster overtook them, and those whose ways of living they admired and wished to imitate completely became their enemies and punished them. For it is no light thing to show irreverence to the divine laws-a fact that later events will make clear.

\section{(2 Macc 4:16-17)}

Note, especially, that although we might expect that those who do what God wants to happen (punish God's sinful people) would be considered respectable, for they are God's agents, in fact, according to this Deuteronomistic conception, that is not the case. Rather, they are wicked, and they do what they do for their own wicked reasons and, as Deut 32:27-29 emphasizes, do not realize that they are, thereby, fulfilling God's purpose. Just as Deuteronomy 32 terms the persecutor "a foolish nation" (Deut 32:21) and Isaiah condemns the Babylonians' arrogance ${ }^{14}$, so too 2 Maccabees, in this context, condemns Antiochus Epiphanes the same way—he is beastly and arrogant $(5: 11,21)$ and did not understand that he succeeded against the Jews only because God allowed him to do so due to their sins (5:17). In fact, however, that is the true story: God, who under normal conditions providentially protects His people against the efforts of the wicked, due to His people's sinfulness "turns His face

13 See esp. the prologue's declaration at 1.14, that the book's chief teaching is that conformance to God's will (i.e., observance of His laws), brings prosperity and happiness, while nonconformance to God's will brings disaster. In general, see Attridge 1976; Klawans 2012, pp. 83-84.

14 See esp. Isaiah, chs. 10 and 14. 
aside" (i.e., ignores His people) and thereby allows free rein to their wicked enemies. ${ }^{15}$ And so too, however surprisingly, we find that even Flavius Josephus, freedman and client of the Flavians, has no problem about terming the Romans simply as "the(ir) (=the Judeans') enemies" (Ant. 18.8), with no effort being made to dignify them as divine agents. Josephus's formulation here bespeaks a traditional point of view, according to which the Romans are merely functionaries in a drama between the Jews and their God. ${ }^{16}$

The same tension, between a story about Judeans and Romans and a story about Jews and their God, frequently pushes its way to the surface in these books. That is because when Jews suffer at the hands of others, Josephus is forced to choose between blaming the apparent villains, namely, those who directly imposed the suffering, or, alternatively, blaming the victims, the Jews themselves, whose sinfulness brought their otherwise providential God to allow those villains free rein. Josephus's strong tendency in the present work to focus on the latter is especially obvious when his narratives are compared to their parallels in his War, written some fifteen years earlier: if there Josephus had tended to blame not only Judean rebels but also corrupt and wicked Roman governors of Judea for the Judeans' misfortunes, now, in Antiquities, while some of the latter remains, time and again we see Josephus emphasizing, instead, the sinfulness of the Judeans themselves, both rebels and others. Thus, for example, Josephus's account of Felix, in Antiquities, is much more concerned than its parallel in War with wicked Jewish rebels ${ }^{17}$, and Josephus's account of Albinus, in Antiquities, is, despite some generalizations about Albinus's wickedness, concerned only with Jewish villains. ${ }^{18}$

Another point to underline is that the Jews' sinfulness about which Josephus complains in Antiquities is not specifically linked to the Temple. It has its results for the Temple, which is destroyed as part of the total catastrophe; but, as opposed to War, which focuses on the pollution of the Temple as that which paved the way to its destruction, in Antiquities the wickedness that Josephus decries is, for the most part, much more general and independent of the Temple, and is formulated as a matter of violating Jewish law. ${ }^{19}$ Jewish law is something available to Jews of the Diaspora, the Temple was not. Even while it still existed, the Jews of the Diaspora perforce had very limited access to it, and by the time Josephus wrote Antiquities, decades had passed since its destruction.

So it happens, that if the moral of the War was one about Judeans and Romans (things would have been just fine if only the Jews had kept their hotheads under control and the Romans had sent honest and wise governors), and about the Jews and their Temple (had they not polluted it, God would not have abandoned it), the moral of Antiquities turned out to be, just as he stated in the prologue (1.14), much more about Jews and their laws and ancestral traditions. That was taken to be a story about Jews and their God, who, whatever the details, was taken to be the author or underwriter of those laws and traditions; if the Jews would not have violated them, things would have been fine. The War's story and

15 See esp. Deuteronomy 32:20; Isaiah 54:7-8; 2 Maccabees 5:17. So too Josephus at War 2.391, 539 and Ant. 20.166. Note, in particular, the parallel between the latter passage's statement, that God meant our suffering "to bring us to our senses" ( $\sigma \omega \varphi \rho o v i ́ \sigma \alpha \iota)$, and 2 Maccabees 6:12; 7:33; 10:4.

16 For this point of view already in the War, see Mason 2005, p. 256, with regard to "God's purging of his own house to purge it of the pollution caused by 'tyrants' (BJ 1. 9-10) [ . . ] the Romans were but useful pawns (cf. BJ 6. 409-13)."

17 See Schwartz 2017.

18 For Jewish sinfulness in Josephus's account of Albinus in Antiquities, see 20.199-200 (Ananus), $205-207$ (high priests), $208-210$ (Sicarii), 211-212 (Agrippa II), 213-214 (high priests and Herodians). The only paragraphs of the account omitted in that list are \$\$201-204, which praise Albinus for listening to respectable Judeans and making a serious attempt to maintain order. See Cohen 1979, p. 60: “The picture of Albinus in AJ [20.]253 does not match the preceding description in AJ[:] In contrast to AJ 20.215 which said nothing of misdeeds by Albinus before the last stage of his career, AJ 20.253-254 implies a long record of malfeasance, in accord only with BJ 2.272-276." See also Schwartz 2011.

19 See Klawans 2012, p. 189, with references to Josephus's allusions, in War, to "bloodshed in and near the Temple" and "the pollution of the temple by bloodshed," and esp. Tuval 2013, pp. 110-15. That all corresponds to Josephus's repeated statement, in War, that destruction was God's way to purify the Temple by fire $(4.323 ; 5.19 ; 6.110)$. In the Antiquities, in contrast, as we have seen, the sins that bring on the catastrophe are more generally phrased as involving changing or abandoning the observance of Jewish law. For another good example of this reorientation in Antiquities, note that Ant. 14.65-67 emphasizes the priests' devotion to the observance of Jewish law (nomoi, nomima), while the parallel in War 1.148-150 emphasizes their devotion to the sacrificial cult (thereapeia). 
its moral were appropriate for someone who grew up in Jerusalem, in the shadow of the Temple, and was well aware of memories of, and hopes for, Jewish sovereignty, and therefore wrote a book that focused on the rebellion as it was, one that bespoke such an agenda. That of Antiquities, in contrast, was appropriate for a book of the Diaspora, when memories of both the Temple and statehood were fading, and it was the Jewish religion, focusing on Jewish law, that was at the heart of Jewish existence.

That distinction between Judean interests and diasporic Jewish interests is, in a nutshell, the distinction between War and Antiquities. The former was written, in the 70s, by a Judean who had just gotten off the boat and settled in Rome; the latter was written in the 90s, by a Jew who was a veteran inhabitant of Rome. ${ }^{20}$ Since, in Antiquities 18-20, the basic framework (from creation of direct Roman rule in Judea to the outbreak of the rebellion) and structure (according to the terms of office of Roman governors of Judea) of Josephus's work pointed not to religion but rather to politics, not to Jews vis-à-vis God but to Judeans vis-à-vis Romans, the result was a significant measure of tension in the work. Whether or not Josephus was aware of it, and whether, if he was, he was incapable of overcoming it, or perhaps hoped to at some later stage, are questions that I cannot answer and matter little.

Apart from Josephus's different situation and orientation in the 90s, as opposed to the 70s, which caused him to focus more on religion than the state and thus engendered tension between his interests and the state-oriented topic and structure of the story, tensions were also created by his use of sources. Such sources had interests of their own, sometimes even vocabularies of their own. Four examples may be noted.

a. War 2. As suggested above, Josephus's War focuses on the history of Judea vis-à-vis Rome, and, for the most part, lacks the tendency to religious orientation that characterizes Antiquities. Yet Josephus did author that earlier work, and it is natural that an author, who is writing about topics or periods that he previously discussed, will remember much of what he wrote in his own earlier work, or actually consult it in preparing a new account of the same period. Indeed, he may even have been proud of this or that formulation, and it could have stuck in his mind. Thus, one way or another, formulations from the War may well have survived in Antiquities despite the fact that they reflect a point of view that no longer guided Josephus. In such cases, his efforts to fit them into his new work, like any author's efforts to make old material fit a new context, were not always successful. Three examples are as follows:

(i) At Ant. 20.182 Josephus refers, in retrospect, to Felix's term of office as governor as if it were mainly characterized by his unjust acts $(\dot{\alpha} \delta \iota \kappa \dot{\eta} \mu \alpha \tau \alpha)$ against his subjects. A review of his account of Felix in Antiquities does not at all justify that; note that Feldman (1965, p. 487, n. f), in his note ad loc., illustrates Josephus's statement here not with references to Josephus's own account, but only with references to Tacitus (Histories 5.9; Annals 12.54). In fact, Josephus' account of Felix in Antiquities is mostly devoted to Jewish villains, with whom Felix tried to deal with, however unsuccessfully. As noted above, in explaining the Jews' troubles, Josephus is now, in Antiquities, focusing on the Jews' sins. Josephus's account in War, in contrast, is much more thoroughly negative about Felix, and so it seems that we must view the summary reference to $\dot{\alpha} \delta \mathrm{s} \kappa \dot{\eta} \mu \alpha \tau \alpha$ in $\S 182$ as a remnant of that point of view.

(ii) At Ant. 20.252-254, similarly, we find the above-mentioned comparison of Florus, who was openly evil, to Albinus, who attempted to hide his criminal behavior. The comparison between the two made perfect sense in War 2.271-277, but in Antiquities there is nothing to substantiate it, because Josephus's account of Albinus, in Antiquities, says next to nothing bad about that governor and in fact is devoted, for the most part, to the villainy of Jewish high priests and their followers; here too, as with Felix, Josephus is focusing on the Jews' sins as an explanation for their troubles. ${ }^{21}$ So just as observed above concerning 20.182's characterization of Felix, so too concerning 20.252-254's characterization of Albinus, it seems, as (Cohen 1979, p. 60) noted, that when returning to his narrative in Antiquities 20,

20 In general, see Schwartz 2014; Tuval 2013.

21 See above, n. 18. 
after the long excursus on the high priests (20.224-251), Josephus simply reverted to his nice transitional comparison between these two last governors, which he either remembered from War 2 or actually found when checking that book to see what he should next be writing.

(iii) At Ant. 20.167-172 Josephus tells two stories about Jewish prophets in Jerusalem in the days of Felix, when he himself was already a young man. He told these stories in War 2.254-263 as well, and there he made it clear that the prophets fomented rebellion against Rome, something which was understood by Felix, who therefore moved forcibly to stamp them out. ${ }^{22}$ In the stories in Antiquities, however, Josephus tells the stories about the prophets without any reference to rebellion, thus leaving readers wondering why the Roman governor intervened. To understand what caused Josephus to leave these stories so mystifying, we must merely recognize that he was in a dilemma: he did not want to omit historical episodes, but now, in the Antiquities and due to his new diaspora-appropriate unwillingness to admit that Jewish religious leaders might foment rebellion against Rome, he had to purge key elements of the stories.

b. High-priestly chronicle. It is evident that Josephus had at his disposal, in composing Antiquities 18-20, a chronicle that listed the names of the successive high priests. Josephus inserted entries from this list at what he thought were appropriate junctures of his narrative, and he also provided a long summary of it at 20.224-251. This material functions as a sort of chronological scaffolding for his narrative, and thus competes with the scaffolding provided by the succession of Roman governors. This causes problems of various sorts. One may be seen in the surprising fact that switches of high priests are often reported around the same time as the transition from one Roman governor to another; that seems to be simply a reflection of Josephus's attempt to force his two systems into one timeline. Here is an example of that, which also illustrates the confusion that can result when snippets of one source are juxtaposed to material from another:

(20.103) King Herod of Chalcis transferred Joseph the son of Kamei from the high priesthood and gave the position to Ananias the son of Nedebaeus in his stead. Cumanus came as the successor of Tiberius Alexander. (104) There then died Herod, the brother of the great king Agrippa, in the eighth year of the reign of Claudius Caesar, leaving three sons: Aristobulus (who had been born to him by his first wife) and-by Berenice, his brother's daughter-Berenicianus and Hyrcanus. Claudius Caesar gave his reign to the younger Agrippa.

I submit, both intuitively and on the basis of experiments with normal readers, that anyone (apart from experts in Herodian history) who reads this passage will probably understand that it refers to two separate Herods, with Josephus taking care, at the opening of $\S 104$, to make sure that readers realize that he is now referring to someone different from the King of Chalcis mentioned at the opening of $\S 103$. In fact, however, the two Herods are one and the same. What happened here is that Josephus, at a break in his narrative, brings us up to date on a number of parallel successions, for which he had separate sources: a high priestly chronicle, which recorded appointments and removals of high priests ( $\$ 103 a)$, a source about the history of Roman Judea (\$103b), and a Herodian source that was interested in the details of that royal family (\$104). The first and the third referred to Herod of Chalcis in two different ways (once by title, once by family), and Josephus preserved their nomenclature. This illustrates, in a very clear way, the difficulties engendered by the attempt to combine materials that reflect very different interests. ${ }^{23}$

22 Note especially War 2.259-260 ("signs of freedom ... outset of insurrection").

23 For other salient examples, see the very end of Book 11 (deaths of Alexander the Great and a Jewish high priest) and 20.196-197 (Agrippa II appoints and then replaces a high priest a sentence before and a sentence after announcing the appointment of a new governor, with nothing said about any causal or other relationship). Note also Ant. 18.95, 123: two appointments made by Vitellius, assigned by Josephus to what he seems to have thought were two visits to Jerusalem but in fact seem to have been one and the same visit; the natural assumption, that Josephus is describing two successive visits, 
c. Other priestly material. Apart from the high priestly chronicle, which seems to have had only laconic listings of appointments and removals from office, Josephus evidently had access to more extensive priestly material as well. Note, for a fairly clear example, the story at 18.90-95. This story betrays the local horizons and interests of Jerusalemite priests: on the one hand, it bespeaks an intense interest in the history of the custody of the high priest's vestments, and uses a bit of Hebrew terminology concerning a part of the Temple ${ }^{24}$; on the other hand, it refers to Archelaus as having ruled as a king ( $\beta \alpha \sigma \iota \lambda \varepsilon \dot{v} \varsigma-\$ 93)$ with the same lack of interest in the niceties of Roman nomenclature as that exhibited by Matthew 2:22 ( $\beta \alpha \sigma \iota \lambda \varepsilon \dot{\varepsilon} \varepsilon \iota)$. Were Josephus not copying uncritically from such a provincial Jewish source, that should have been nigh impossible for someone who devoted scores of paragraphs in Antiquities 17 to the dispute among Herod's heirs and Augustus's final decisions concerning their territories and titles. Moreover, the passage creates a major chronological difficulty, which, it appears, should be resolved by the assumption that it describes, from a particular point of view (namely, that of the Jerusalem priesthood), the same event described, from another point of view, in the continuation of Josephus's narrative, which focuses on political affairs. ${ }^{25}$

d. Roman material. Here, first of all, we should relate to Antiquities 19, which constitutes a very lengthy and detailed account of the assassination of Gaius Caligula. It is clear that Josephus used Roman sources for this narrative, ${ }^{26}$ and just as clear that they were not written in order to relate anything about how Jerusalem and the Temple came to be destroyed. Rather, they were concerned with the clash between the tyrant and the Senate and had their own message(s) about why, despite the assassination, the Senate did not manage to regain power and restore the Republic. Moreover, Josephus very evidently used pro-Agrippa I materials, which focused on magnifying his role in Claudius's rise to the throne ${ }^{27}$ - a role that focused on hoodwinking the Senate. There is, obviously, quite a conflict between a source that bemoans the Senate's lack of courage and savoir faire, which ended up letting the few brave assassins die as martyrs while the Empire maintained itself, and one that praises Agrippa for his role in marginalizing the Senate and brokering Claudius's ascent to the throne. Josephus did his best with that conflict, and also tried to make the whole story fit into Antiquities in two ways. First, he proclaims, at the outset of the story, that he was telling it because it demonstrated divine providence: "it affords much reason to believe in the power of God, consolation for those who are down in their fortunes, and sobriety for those who think that good fortune is eternal and will not take a turn for the worse if not accompanied by virtue" (19.16). This is standard Josephan formulation, used similarly at 18.127 , but while there it does fit the continuation, here, in the story of Gaius's assassination, there is nothing to justify it nor, indeed, any interest in the theme. The second way is by ending the relatively short story of Agrippa I, which follows that of Gaius's assassination and completes Book 19, with a story about how Agrippa was recognized as a god and immediately afterward was stricken with an intense mortal illness and died, not without first recognizing the power of the true God (19.344-350). Juxtaposition of this story (which is paralleled by that at Acts 12: 20-23) to that of Gaius, who had demanded to be revered as a god, suggests that Gaius's death too was divine punishment for such hubris. Yet given the lack of any such suggestion in the long story of the assassination itself (19.17-273), the artificial nature of this suggestion, and the ease with which (as experience shows) readers might not notice it, are quite evident.

famously engenders an insoluble chronological difficulty. That is, Josephus thought he was assigning the two separate entries in the high-priestly list to two different historical contexts, but he was wrong. See Schwartz 1992, p. 213.

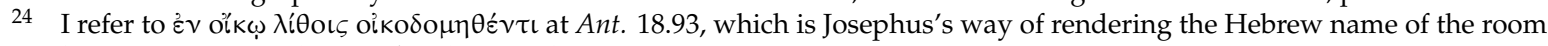
known as Bet Even (m. Parah 3:1). See Schwartz 2006.

25 See above, n. 23.

26 For attempts to delineate, characterize, and identify them, see, inter alia, Destinon 1904, pp. 3-14; Timpe 1960; Feldman 1962; Goud 1996; Scherberich 2001; and Wiseman 2013, pp. xiv-xvi.

27 See esp. Ant. 19.236, 242-245. 
Other Roman material can be identified elsewhere in these books, especially in reports that relate to foreigners the Romans liked to despise, be they priests of Isis in Rome (18.65-84) or Greek freedmen. ${ }^{28}$ If Josephus was able to integrate the former material successfully into his story, by explicitly using the priests of Isis as foils for the Jews $\left(18.65,80^{29}\right)$, his use of anti-freedmen material in his account of Felix brought him into conflict with his own tendencies, for while Romans liked to blame corrupt Greeks for the Romans' problems in Judea, Josephus, in the Antiquities, preferred to blame bad Jews, and the result was, as with Albinus, that he left us with a narrative that pulls in contrary directions. ${ }^{30}$

We are left, then, with three books that, while dealing with a political topic and structured for a political topic, and while placed at the end of the second decade of Antiquities in such a way that focus on Roman rule is all the more clear, nonetheless show us an author who is actually more interested in the Jewish religion that survived that destruction. Moreover, tension was introduced into the book not only by the author's religious orientation, which pulled in a direction that did not conform naturally to the book's Judean versus Roman topic and structure; it was also introduced by his use of sources, which had agendas and interests of their own. Recognition of these roots of tension can allow us to understand why, here and there, the book's story is less than coherent, and thus also allow us to reconstruct something of the development of Josephus's own views, as well as something of the plurality of views current in his days, many of which did not manage to survive independently.

Funding: This research received no external funding.

Conflicts of Interest: The author declares no conflict of interest.

\section{References}

Attridge, Harold W. 1976. The Interpretation of Biblical History in the Antiquitates Judaicae of Flavius Josephus. Harvard Dissertations in Religion 7. Missoula: Scholars Press.

Barnes, T.D. 2005. The Sack of the Temple in Josephus and Tacitus. In Flavius Josephus and Flavian Rome. Edited by Jonathan Edmondson, Steve Mason and James Rives. Oxford: Oxford University Press, pp. 129-44.

Cohen, Shaye J. D. 1979. Josephus in Galilee and Rome: His Vita and Development as a Historian. Columbia Studies in the Classical Tradition 8. Leiden: Brill.

Destinon, Justus von. 1904. Untersuchungen zu Flavius Josephus. Wissenschaftliche Beilage zur Jahresbericht des kgl. Gymnasiums zu Kiel. Kiel: Fienke.

Feldman, Louis H. 1962. The Sources of Josephus' “Antiquities”, Book 19. Latomus 21: 320-33.

Feldman, Louis H. 1965. Josephus, Jewish Antiquities: Books XVIII-XX. Loeb Classical Library. London: Harvard University Press.

Feldman, Louis H. 1998. Josephus's Interpretation of the Bible. Berkeley: University of California Press.

Goud, Thomas E. 1996. The Sources of Josephus Antiquities 19. Historia 45: 472-82.

Klawans, Jonathan. 2012. Josephus and the Theologies of Ancient Judaism. Oxford: Oxford University Press.

Mason, Steve. 2005. Figured Speech and Irony in T. Flavius Josephus. In Flavius Josephus and Flavian Rome. Edited by Jonathan Edmondson, Steve Mason and James Rives. Oxford: Oxford University Press, pp. 243-88.

28 On the latter, see, apart from Ant. 20.182-183, also ibid. §§135-137 and Schwartz 2017, pp. 381-83.

29 Namely, Josephus emphasizes, in his summary of the first story, that it was priests of Isis (i.e., presumably, respectable and representative members of the Egyptian community) who were responsible for the crime (\$80). That creates a clear contrast with the second story, in which he begins by characterizing the Jewish perpetrators as criminal types (i.e., not representative of Jews at large), and concludes by underlining, as if it was unfair, the fact that all the Jews of Rome were exiled due to the crime of only four men (§84).

30 On Josephus on Felix, see Schwartz 2017. As for Albinus, see esp. 20.215. This passage, of which the tone is "peculiarly ambiguous and/or self-contradictory" (Cohen 1979, p. 62), begins by reporting that Albinus wished to be well thought of and therefore justly punished severe offenders but released from prison those who had been imprisoned for only "minor and mundane reasons." That sounds laudatory. Then, however, Josephus goes on to complain that, as a result of his action, the country became full of brigands-which should not have happened, if only small fry were released. (It might also be that Josephus additionally condemns Albinus, in this passage, when he reports that Albinus took money from the minor offenders that he released; perhaps that means, as Cohen (ibid.) assumes, that he took bribes. However, Josephus might mean only that Albinus allowed them to convert imprisonment into fines). 
Millar, Fergus. 2005. Last Year in Jerusalem: Monuments of the Jewish War in Rome. In Flavius Josephus and Flavian Rome. Edited by Jonathan Edmondson, Steve Mason and James Rives. Oxford: Oxford University Press, pp. 101-28.

Scherberich, Klaus. 2001. Josephus und seine Quellen im 19. Buch der Antiquitates Iudaicae (ant. Iud. 19, 1-273). Klio 83: 134-51. [CrossRef]

Schürer, Emil. 1874. Lehrbuch der Neutestamentlichen Zeitgeschichte. Leipzig: Hinrichs.

Schürer, Emil. 1973-1987. The History of the Jewish People in the Age of Jesus Christ (175 B.C.-A. D. 135). 3 vols. Edinburgh: T. and T. Clark.

Schwartz, Daniel R. 1992. Studies in the Jewish Background of Christianity. Wissenschaftliche Untersuchungen zum Neuen Testament 60. Tübingen: Mohr (Siebeck).

Schwartz, Daniel R. 2006. "Stone House," Birah and Antonia during the Time of Jesus. In Jesus and Archaeology. Edited by James H. Charlesworth. Grand Rapids: Eerdmans, pp. 341-48.

Schwartz, Daniel R. 2011. Josephus on Albinus: The Eve of Catastrophe in Changing Retrospect. In The Jewish Revolt against Rome: Interdisciplinary Perspectives. Supplements to the Journal for the Study of Judaism 154. Edited by Mladen Popović. Leiden: Brill, pp. 291-309.

Schwartz, Daniel R. 2014. Judeans and Jews: Four Faces of Dichotomy in Ancient Jewish History. Toronto: University of Toronto Press.

Schwartz, Daniel R. 2015. Josephus between the Flavians and God: On the Duality of The Judean War. In Milestones: Essays in Jewish History Dedicated to Zvi (Kuti) Yekutiel. Edited by Immanuel Etkes, David Assaf and Yosef Kaplan. Jerusalem: Zalman Shazar Center, pp. 33-41. (In Hebrew)

Schwartz, Daniel R. 2017. "Going up to Rome" in Josephus's Antiquities. In Journeys in the Roman East: Imagined and Real. Culture, Religion, and Politics in the Greco-Roman World 1. Edited by Maren R. Niehoff. Tübingen: Mohr Siebeck, pp. 373-88.

Timpe, Dieter. 1960. Römische Geschichte bei Flavius Josephus. Historia 9: 474-502.

Tuval, Michael. 2013. From Jerusalem Priest to Roman Jew: On Josephus and the Paradigms of Ancient Judaism. Wissenschaftliche Untersuchungen zum Neuen Testament II/357. Tübingen: Mohr Siebeck.

Wiseman, T.P. 2013. The Death of Caligula: Josephus, Ant. Iud. XIX 1-273. Liverpool: Liverpool University Press.

(C) 2020 by the author. Licensee MDPI, Basel, Switzerland. This article is an open access article distributed under the terms and conditions of the Creative Commons Attribution (CC BY) license (http://creativecommons.org/licenses/by/4.0/). 